\title{
MICROSTRUCTURE AND MECHANICAL PROPERTIES OF HOT
}

\section{PRESSED 16.5CR FERRITIC ODS STEEL DEVELOPED}

\section{THROUGH MECHANICAL ALLOYING}

\section{G. DHARMALINGAM, R. MARIAPPAN \& M. ARUN PRASAD}

Department of Mechanical Engineering, Vel Tech Rangarajan Dr. Sagunthala R\&D Institute of Science and Technology, Avadi, Chennai, Tamil Nadu, India

\begin{abstract}
Two different ferritic oxide-dispersion-strengthened (ODS) steels compositions $\mathrm{Fe}-16.5 \mathrm{Cr}-0.89 \mathrm{Mn}-0.3 \mathrm{Y}_{2} \mathrm{O}_{3}-$ $2 \mathrm{ZrO}_{2}$ (Sample1) and $\mathrm{Fe}-16.5 \mathrm{Cr}-0.89 \mathrm{Mn}-0.3 \mathrm{Y}_{2} \mathrm{O}_{3}-2 \mathrm{ZrO}_{2}-2 \mathrm{Al}$ (Sample2) were prepared through Mechanical Alloying (MA) and X-Ray Diffraction (XRD) pattern were taken at different time intervals for confirming the Nano-crystallite size. Milled powders were consolidated at $1170^{\circ} \mathrm{C}$ at three different pressure levels of 30,40 and $60 \mathrm{MPa}$ respectively. Densification studies, microstructural examination, and mechanical properties evaluation were analyzed and reported in the current study. MA of the hot pressed powder at $60 \mathrm{MPa}$ obtained the highest density, hardness , and tensile strength compared with another pressure compact irrespective of its composition. Aluminum addition in the ferritic ODS steel lowers the density, hardness, and elongation of the ferritic ODS steel samples.

KEYWORDS: Ferritic ODS Steel, Mechanical Alloying (MA), Vacuum Hot Pressing (VHP), Crystallite Size.\& Hot Pressing
\end{abstract}

Received: Jan 31, 2018; Accepted: Feb 21, 2018; Published: Mar 13, 2018; Paper Id.: IJMPERDAPR201882

\section{INTRODUCTION}

High-chromium (Cr) ferritic stainless steels (FSS) are widely used for the heat resistant structural applications in nuclear, thermal power plants and fast breeder reactors. FSS has body -centered cubic crystal structure combined with good swelling resistance, low coefficient of thermal expansion, high thermal conductivity, good oxidation, creep resistance and high tensile/compressive strength at an ambient and elevated temperature which favors the high temperature application [1,2]. However, the utility of FSS is limited to temperatures up to $550{ }^{\circ} \mathrm{C}$, because of the lack of inadequate creep strength above this temperature $[3,4]$. In order to overcome these drawbacks, the matrix is strengthened with nano - oxide dispersed strengthening which would prevent grain boundary sliding and improves strength at room and at elevated temperatures [5]. It has been demonstrated that oxide-dispersion-strengthened ferritic steels/alloys can maintain good mechanical properties at elevated temperatures and have greater swelling resistance than the austenitic steels $[6,7]$. Compared with conventional ferritic/martensitic steels, oxide dispersion strengthened steels have higher resistance to neutron irradiation embrittlement and void swelling because the highly stable nano-sized oxide particles could act as effective barriers to the motion of dislocations [6,8]. Oxide dispersion strengthened (ODS) ferritic steel which contains a high number density of small oxide particles has been considered as one of the most promising structural materials for advanced nuclear applications [9]. Due to the unique microstructure, the ferritic ODS steels show excellent hightemperature tensile properties, creep resistance and promising irradiation resistance $[10,11]$. For fission application, 
the $\mathrm{Cr}$ content in ODS steels is usually in the range of 9-14\% [12]. However, the low-Cr-ODS ferritic/martensitic steels are not suitable for supercritical water reactor (SCWR) owing to an insufficient corrosion resistance of the materials. Corrosion resistance of iron -based alloys is influenced by chromium. The $\mathrm{Cr}$ content can be balanced between a merit of corrosion resistance and a demerit of aging embrittlement with maintaining strength at elevated temperatures [13].

Many researchers reported that high content of chromium (>13\%) in the ODS steel was very effective for suppressing corrosion. On the other hand, there was also a limitation to chromium addition, because high chromium content usually resulted in a thermal aging embrittlement. Alamo et. al studied the high- temperature behavior of $14 \mathrm{Cr}$ ferritic ODS steel of two different microstructures [4, 14]. They stated that the high- temperature strength of high chromium ferritic steel is determined by several parameters like oxide particle distribution, grain size ,and texture. Moreover, they concluded that fine grain structure in $14 \mathrm{Cr}$ ferritic steel increases the high -temperature strength and lowers Ductile to Brittle Transition Temperature (DBTT), but the intermediate recrystallized structure enhances the ductility and creeps properties $[15,16]$. He et al (2012) reported that ultimate tensile strength of $14 \mathrm{Cr}$ ferritic steel is superior to the $9 \mathrm{Cr}$ ferritic steel $[10,17,18]$. The addition of more chromium $(<18 \%$ to $>13 \%)$ in the ferritic ODS steel enhances tensile strength and corrosion resistance [19-22]. However, the addition of aluminum in high chromium steel led to the coarsening of the oxide particles, which decreases the high-temperature strength [23]. On the other hand, the addition of zirconium to ferritic matrix could effectively translate into better performance of Al-alloyed ODS steels against high temperature and corrosion. This is because the binding energy of Yittrium-Zirconium (Y-Zr) oxides in an iron matrix is higher than that of Yittrium-Aluminum ( $\mathrm{Y}-\mathrm{Al}$ ) oxides, thus $\mathrm{Y}-\mathrm{Zr}$ oxides are easier to form and more stable than $\mathrm{Y}-\mathrm{Al}$ oxide particles [24-26]. For this reason, it is expected that the addition of zirconium to the matrix prevents the oxygen to combine with aluminum, refining the oxide particles and increasing their number density [24]. These changes in the size and density of the oxides will ultimately lead to an improvement of high-temperature strength while keeping the high corrosion resistance of Al-alloyed ODS steels [27, 28].

The present investigation aims towards the synthesizing of nano- oxide dispersed strengthened steels by adding yttria, zirconia and aluminum with $16.5 \mathrm{Cr}$ ferritic steels through the mechanically alloying process. Milled powders were consolidated at a temperature of $1170{ }^{\circ} \mathrm{C}$ with different pressure levels. Hot pressed steels were subjected in to densification studies, microstructural examination, X-ray diffraction (XRD) analysis, Scanning electron microscope (SEM) studies and evaluation of mechanical properties to establish the structure-property process parameter of the alloy.

\section{EXPERIMENTAL PROCEDURE}

The experimental steps followed in this investigation are MA of the powders and their consolidation by means of Vacuum Hot Pressing (VHP) to obtain the designed ODS steels.

Table 1: Chemical Composition of Ferritic Steels and Its Mixtures

\begin{tabular}{|l|c|c|c|c|c|c|c|c|}
\hline Powder Grade & $\mathbf{C r}$ & $\mathbf{M n}$ & $\mathbf{S i}$ & $\mathbf{C}$ & $\mathbf{P}$ & $\mathbf{S}$ & $\mathbf{F e}$ & Theoretical Density (g/cc) \\
\hline $430 \mathrm{~L}$ & 16.5 & 0.89 & 0.89 & 0.02 & 0.01 & 0.01 & $\mathrm{Bal}$ & - \\
\hline Sample 1 & \multicolumn{7}{|l}{$\left(430 \mathrm{~L}+0.3 \mathrm{Y}_{2} \mathrm{O}_{3}+2 \mathrm{ZrO}_{2}\right) \mathrm{wt} \%$} & 7.64 \\
\hline Sample 2 & $\left(430 \mathrm{~L}+0.3 \mathrm{Y}_{2} \mathrm{O}_{3}+2 \mathrm{ZrO}_{2}+2 \mathrm{Al}\right) \mathrm{wt} \%$ & 7.54 \\
\hline
\end{tabular}




\section{Mechanical Alloying of Ferritic ODS Powder}

Sample 1 and sample 2 were developed from $430 \mathrm{~L}$ pre-alloyed powders with the addition of yttria, zirconia and aluminum having a theoretical density of $7.64 \mathrm{~g} / \mathrm{cc}$ and $7.54 \mathrm{~g} / \mathrm{cc}$ respectively as shown in table 1 . A base alloy consisting of 430L pre-alloyed powder was procured from SANDVIK company with the average particle size of $-22 \mu \mathrm{m}$ with the purity level of $99 \%$, the chemical composition of 430L ferritic stainless steel as shown in Table 1 summarizes the compositions designed for this investigation. Yttria (III) was procured from $\mathrm{M} / \mathrm{s}$ Jiaton, China with the average particle size of 700nm. Zirconium oxide powder with the particle size of - 325 mesh size was procured from M/s Otto Chemie pvt. Ltd., Mumbai. Elemental aluminum powder $(-67 \mu \mathrm{m})$ were purchased from Metal Powder Company, Thirumangalam, Tamilnadu. Mechanical Alloying processes were performed by high-energy planetary Fritsch Pulversitte PM400 milling equipment under a normal atmosphere with a constant flow using stainless steel vial and balls (10mm diameter) [29, 30]. The planetary ball mill was operated at $300 \mathrm{rpm}$ for 20 hours with a ball-to-powder weight ratio of 10:1. The milling was carried out on toluene medium because it acts as an additive (diluents/ coolant) and restricts the combustion event. It avoids inter-particle agglomeration during collisions, which results in a reduction of particle size. The phase evolution of powder samples at different stages of mechanical milling $(0 \mathrm{~h}, 10 \mathrm{~h}, 15 \mathrm{~h}, 20 \mathrm{~h})$ was collected and phase transformation of the powder samples was analyzed through X-Ray Diffractometer using the $\mathrm{Cu} K \alpha(\lambda=1.542 \AA)$ in a Philips X-pert MPD. Crystallite size and lattice strain of the milled powder were calculated using Debye's-Scherrer method. Moreover, the powder morphology and size of the milled powders at different stages of milling was studied by means of scanning electron microscopy (JEOL/EO) with an accelerating voltage of $15 \mathrm{kV}$ and a working distance of $11.5 \mathrm{~mm}$. The theoretical density of the above said compositions stated in Table 1 were calculated through the rule of mixture. Milled powders were unusally hot pressed in a vacuum hot press at a temperature of $1170^{\circ} \mathrm{C}$ with the holding time of $90 \mathrm{~min}$, at different pressure levels such as $30 \mathrm{MPa}, 40 \mathrm{MPa}$, and $60 \mathrm{MPa}$. The rate of heating was $5^{\circ} \mathrm{C}$ per min after hot pressing furnace cooling was performed. Dimensions of 20mm diameter and $6 \mathrm{~mm}$ height steel samples were hot pressed using suitable graphite die and punch assemblies. Throughout the experiment, the vacuum level of $10^{-3}$ Torr was maintained. Consolidated hot pressed sample densities were evaluated using mass and physical dimensions. Hot pressed samples were metallographically polished and etched using Kalling's reagent $\left(5 \mathrm{gm} \mathrm{CuCl}_{2}+100 \mathrm{cc} \mathrm{HCl}+100 \mathrm{cc}\right.$ Ethyl alcohol) and observed under an optical microscope (Metscope -I, Chennai Metco Pvt. Ltd., India). SEM with Energy Dispersive Spectrum (EDS) was taken from the hot pressed consolidated samples. The hardness of the hot pressed samples was measured using Rockwell hardness tester (C-scale) with an applied load of $150 \mathrm{kgf}$, dwell timer $10 \mathrm{~s}$ and $1 / 16^{\text {th- }}$ inch steel ball indenter. Room temperature tensile properties of the hot pressed samples were carried out using Hounsfield transmitter (Kundale India Ltd, India) as per ASTM-(E8 standard with astrain rate of $1 \mathrm{~mm} / \mathrm{min}$.

\section{RESULTS AND DISCUSSIONS}

\section{XRD Pattern of Crystallite Size with Different Milling Times}

XRD patterns of the aluminum free (sample 1) and aluminum containing ferritic ODS steels (sample 2) are shown in the figures 1 and 2 respectively. XRD patterns clearly revealed that milling time influences the peak broadening with irrespective of compositions of both sample 1 and sample 2. Longer milling time (20 hours) has driven more broadening of peaks, which indicates that nanocrystallite size of the composition was attained and broadening of the $\alpha$-Fe peak is shown more clearly in 20 hours of milling. During mechanical alloying, the particles have undergone various stages in fracture, cold welding and formation of the solid solution [31]. However, the additions of yttria and zirconia peaks were not 
observed in the XRD pattern due to lower content. XRD pattern of sample 2 (figure 2) has the individual ferrite and aluminum peaks for enamelled powder (0 hours milled powder). During mechanical alloying of sample 1 and sample 2 have similar trends of phase transformation and structures, which is evident from the XRD patterns from sample $1 \& 2$ (figure 1\& figure.2).The Crystallite size of the milled powders was measured by using Debye's Scherrer formula and is found to be $3.5 \mathrm{~nm}$ and $2.6 \mathrm{~nm}$ for sample 1 and sample 2 respectively. Addition of aluminum in ferritic steel leads to substantial reduction of crystallite size of the solvent and assists the disintegration of all solute atoms present in the composition (sample 2) to a single phase solid solution due to Gibbs - Thompson Effect [32].

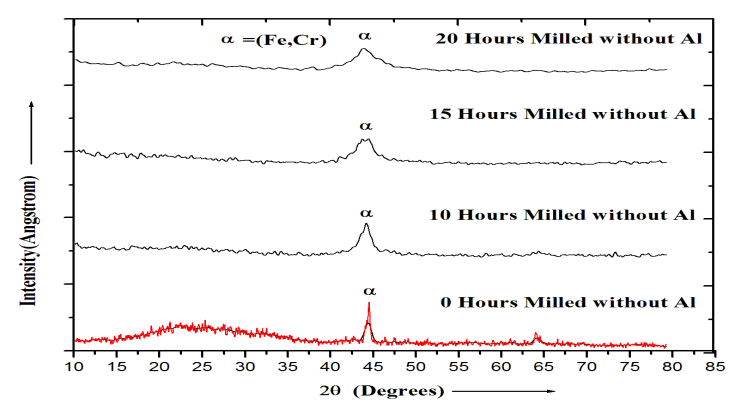

Figure 1: XRD Patterns of Mechanical Alloyed Sample 1 at Different Time Intervals

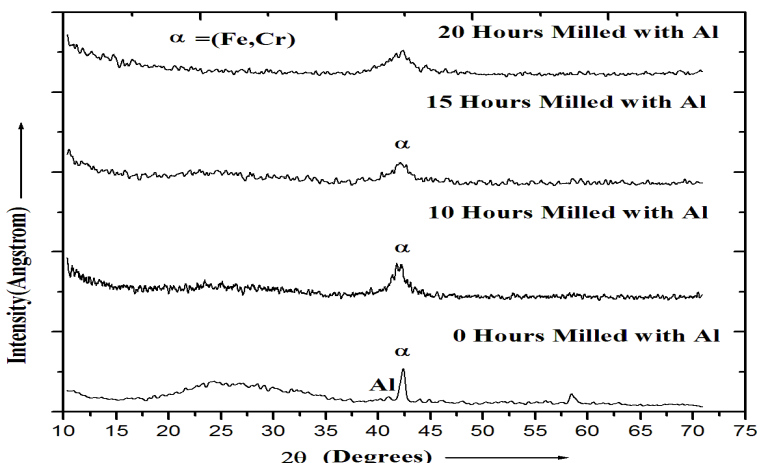

Figure 2: XRD Patterns of Mechanical Alloyed Sample 2 at Different Time Intervals

During the Mechanical alloying (MA), broadening of X-ray diffraction (XRD) peaks with increasing milling time was observed and this is due to the reduction in crystallite size and an increase in lattice strain.

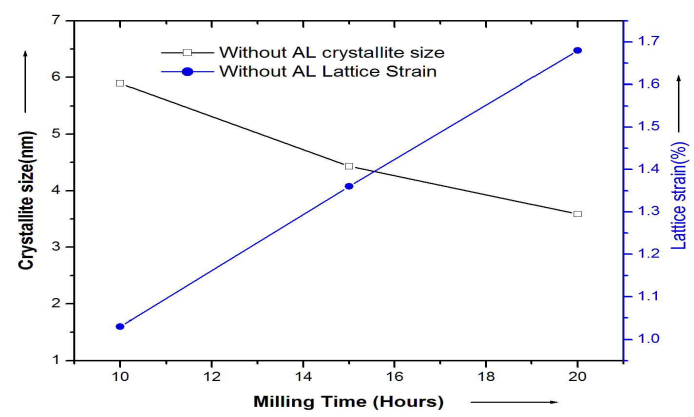

Figure 3: Relation between Crystallite Size and Lattice A strain of Mechanical Alloyed Sample 1 


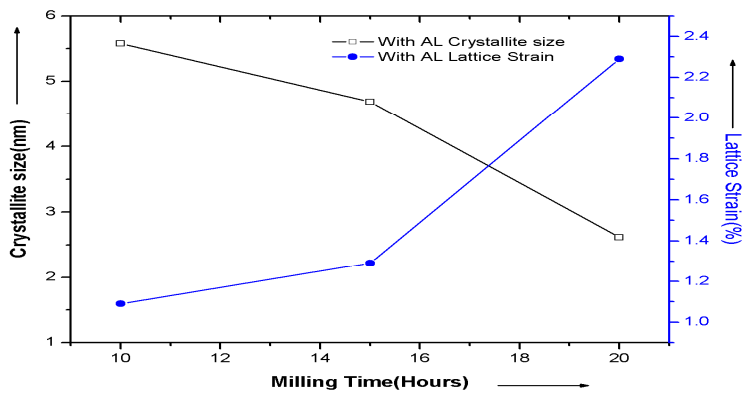

Figure 4: Relation between Crystallite Size and Lattice Strain of Mechanical alloyed Sample 2

XRD analysis of the MA powder indicated broadening of the $\alpha$-Fe peak. Further the XRD analysis reveals an increase in the solid solubility of the solute elements in the $\alpha$-Fe matrix. An increase in the lattice strain as well as the gradual reduction of the crystallite size as it was confirmed in Figure 3 and 4 respectively. It is observed that in the above graphs the crystallite size gradually decreases and lattice strain increases with increase in milling time. The crystallite size of mechanically alloyed powders (sample 1) after 20h of milling as shown in (figure 3) was $3.5 \mathrm{~mm}$ and the lattice strain rate was $1.68 \%$. Similar decreases in the crystallite size of mechanically alloyed powders (sample-2) after 20h of milling, as shown in (figure 4), was $2.6 \mathrm{~nm}$ and increases the strain rate was $2.29 \%$.

\section{SEM Morphology of Mechanical Alloyed Milled Powder Samples}

SEM powder morphologies of mechanically alloyed sample 1 and sample 2 at different time intervals are shown in figure 5. Figure 5a \& 5 b have shown the un-milled powder morphology of sample 1 and sample 2 respectively. From the figure $5 \mathrm{a} \& 5 \mathrm{~b}$, samples 1 and 2 have an identical spherical shape of pre-alloyed powder with irregular fine sized yttria and zirconia particles. The little amount of flaky aluminum particles is also observed for the sample 2 compositions. During mechanical alloying particles have undergone various fracture mechanism due to high impact collision of balls with particles [27]. Size reduction during mechanical alloying is clearly observed for 10 hours of milling. Cold welding was also exhibited during longer milling time, hence mechanically alloying have agglomerated fine particles into micron size [33]. Finally, at 20 hours of milling has reduced the crystallite into nano size.
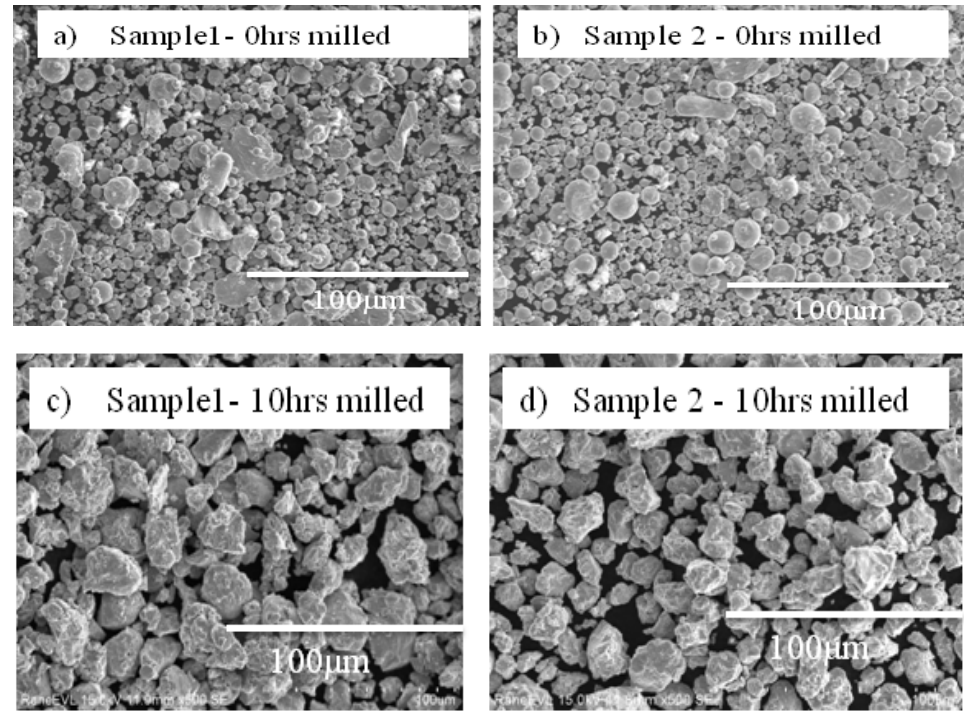

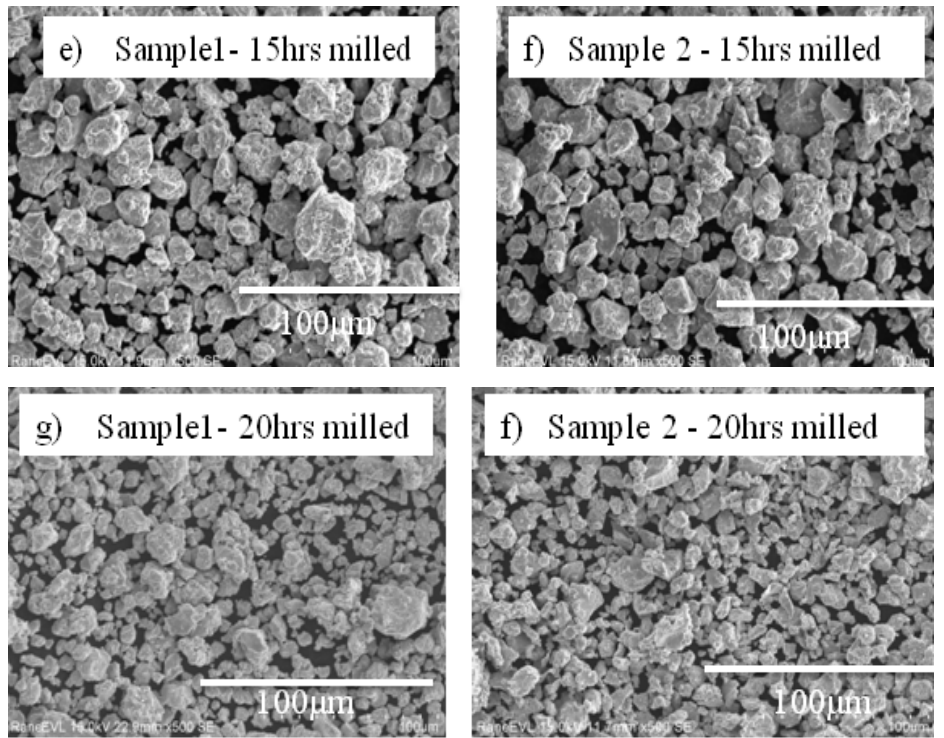

Figure 5: SEM Powder Morphology of Milled Powders at Different Time Intervals

\section{Density Analysis of Hot Pressed Samples at Different Pressure}

Density bar graphs of sample 1 and sample 2 with different consolidation pressure such as $30 \mathrm{MPa}, 40 \mathrm{MPa}$, and 60 $\mathrm{MPa}$ are shown in figure 6. From the graph it is observed that increasing pressure at high temperature enhanced the hotly pressed density. Sample 1 is having the densities of $6.7 \mathrm{~g} / \mathrm{cc}, 6.9 \mathrm{~g} / \mathrm{cc}$, and $7.32 \mathrm{~g} / \mathrm{cc}$ for the pressure levels of $30 \mathrm{MPa}$, $40 \mathrm{MPa}$, and 60MPa respectively. Similarly sample 2 is having the densities varying from $6.66 \mathrm{~g} / \mathrm{cc}, 6.84 \mathrm{~g} / \mathrm{cc}$,and $7.18 \mathrm{~g} / \mathrm{cc}$. From the densification studies, it is observed that aluminum- containing ferritic ODS steels (sample 2) have lesser sintered density than the aluminum free ferritic ODS steel (sample 1) irrespective of its pressure levels [34]. During hot pressing,the formation of coarse $\mathrm{Y}-\mathrm{Al}-\mathrm{Zr}-\mathrm{O}$ complex oxides in the sample 2 has made volume expansion, which slightly reduced the hotly pressed density. But the aluminum free samples have very fine complex oxides of $\mathrm{Y}_{2} \mathrm{O}_{3}$ and $\mathrm{ZrO}_{2}$ which led to higher hotly pressed density than the aluminum containing ferritic ODS steels. Aimilar trend was observed by Andrea Garcia et.al (2016) for the $14 \mathrm{Cr}$ ferritic steel with and without the addition of aluminum [35]. Influence of hot pressure also additional effect for improving density after hot pressing. High pressure (60 MPa) at elevated temperature has enhanced the density with irrespective of its composition.

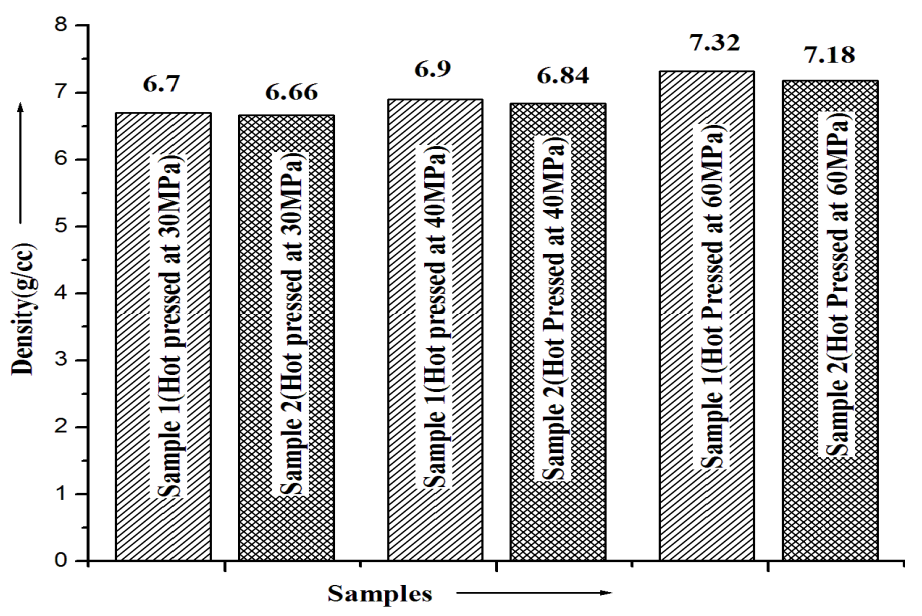

Figure 6: Hot Pressed Densities of Sample 1 and Sample 2 at Different Pressure Levels 


\section{Micro structural Analysis of Hot Pressed Samples}

Microstructures of hot pressed sample 1 and sample 2 are shown in the figure.7a and $7 \mathrm{~b}$ respectively. The microstructure consists of lamellae structure along with dark island under ferritic matrix was observed. Addition of aluminum in the ODS ferritic steel composition has slightly reduced lamellar structure, which is evident from the microstructure (figure7b). Sample 1 and
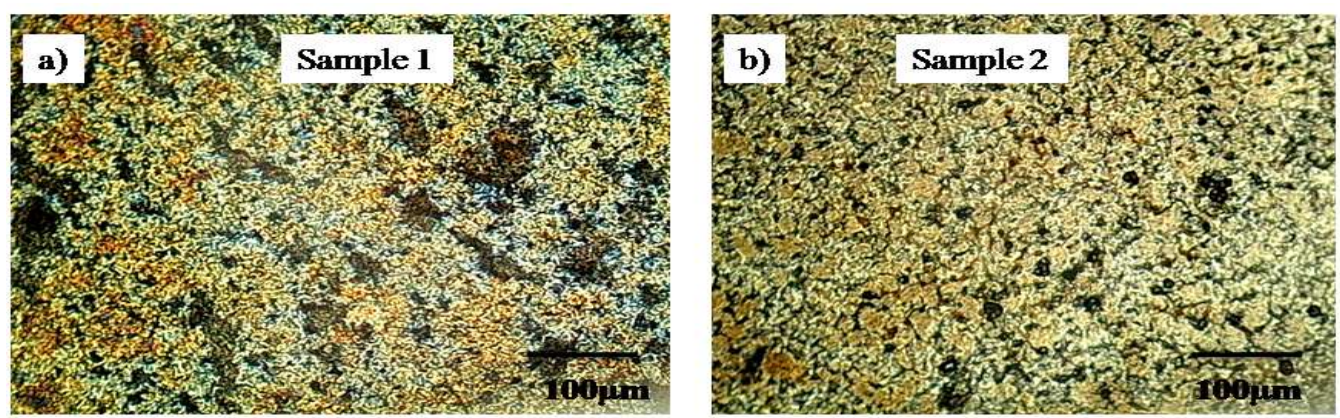

Figure 7: Microstructures of Hot Pressed Sample 1 and Sample 2 at 100X

Sample 2 are completely analyzed through SEM-EDS, which are shown the figures $8 \& 9$ respectively. A EDS analysis of the sample 1 has shown the presence of ferrite with complex oxides, elemental mapping confirms the complex oxides consists of Y-Zr-O. Ferrite phase in the composition was stabilized by the elements such as Fe and chromium [36]. But EDS elemental mapping of aluminum containing ferritic steel (sample 2) showed the oxide containing Al-Zr-Y-O in the defined area $[35,37]$.
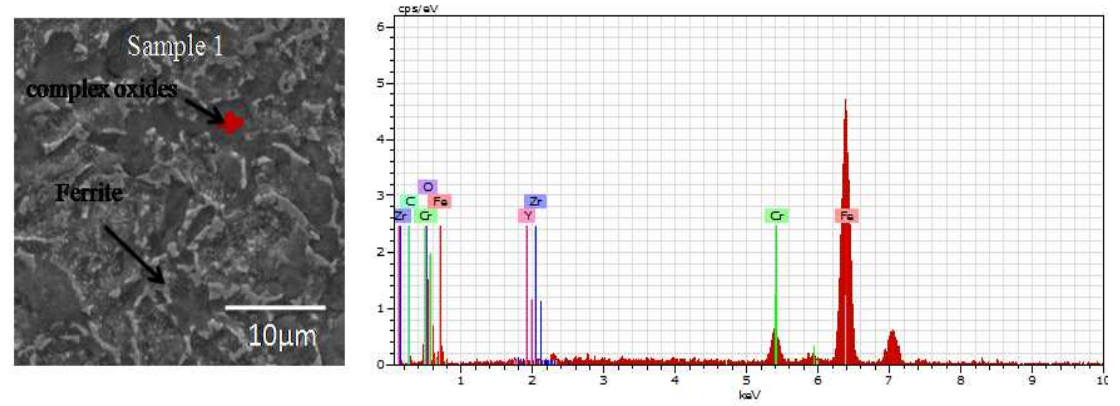

Figure 8: SEM - EDS Analyses at Oxide Regions of Hot Pressed Sample 1
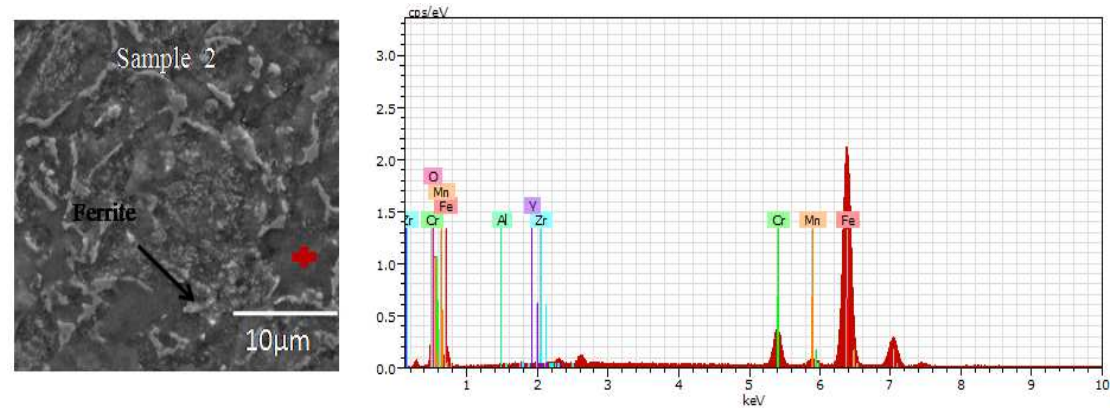

Figure 9: SEM - EDS Analyses at Oxide Regions of Hot Pressed Sample 2

\section{Mechanical Properties of Hot Pressed MA Ferritic Steels}

Tensile strength and percent elongation of hotly pressed sample 1 and sample 2 are shown in the figure 10a and 
10b. Sample 1 (Fe-16.5Cr-0.3Y-2 $\left.\mathrm{ZrO}_{2}\right)$ has exhibited higher tensile strength of $584 \mathrm{MPa}$, which has $7 \%$ higher tensile strength than the aluminum containing ferritic ODS steel (548 MPa) [38]. Addition of aluminum in the sample 2 (Fe$16.5 \mathrm{Cr}-0.3 \mathrm{Y}-2 \mathrm{ZrO}_{2}-2 \mathrm{Al}$ ) hascoarsened the complex oxides, which lead to a reduction in tensile strength [23, 28]. However, improved ductile properties of $16 \%$ elongation were obtained for sample 2, presence of aluminum in sample 2 has made it very soft and improved the ductility. Chemical composition has also influenced the hardness of the hotly pressed steel. Sample 1 has the higher hardness of $43 \mathrm{HRC}$ than the sample 2 (37 HRC), which is shown in figure 11 . Fine Y-Zr-O complex oxide on the aluminum free
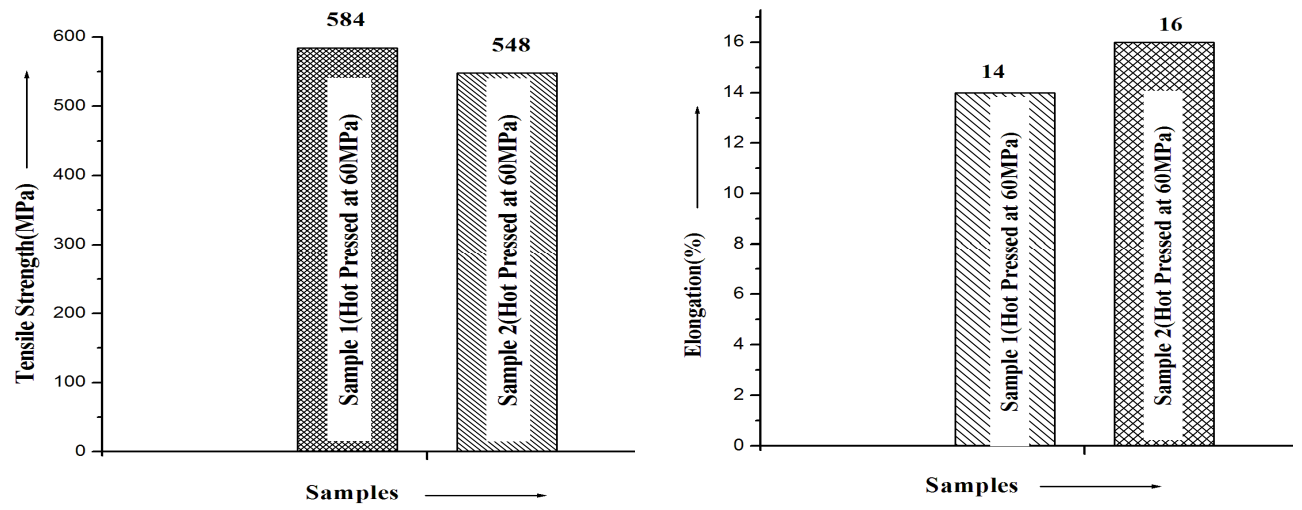

Figure 10: Tensile Strength and Percent Elongation of Hot Pressed Sample 1 and Sample 2 Pressed At $1170^{\circ} \mathrm{C}$

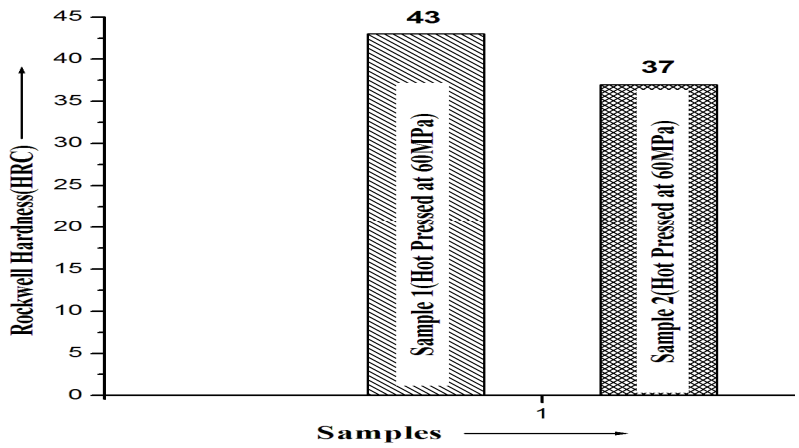

Figure 11: Hardness Number of 16.5Cr Ferritic ODS Steels Hot Pressed at Different Pressures at $1170^{\circ} \mathrm{C}$

ferritic steel (sample 1) enhanced hardness and strength by the dispersion strengthening effect, which was reported several researchers [39]. Aluminum free (Sample 1) $16.5 \mathrm{Cr}$ ferritic steel has $14 \%$ higher hardness than the aluminum containing (Sample 2) ferritic steel at the pressure level of 60MPa [40].

\section{CONCLUSIONS}

Two different ferritic ODS steel such as sample $1\left(\mathrm{Fe}-16.5 \mathrm{Cr}-0.89 \mathrm{Mn}-0.3 \mathrm{Y}_{2} \mathrm{O}_{3}-2 \mathrm{ZrO}_{2}\right)$ and sample $2(\mathrm{Fe}-16.5 \mathrm{Cr}-$ $\left.0.89 \mathrm{Mn}-0.3 \mathrm{Y}_{2} \mathrm{O}_{3}-2 \mathrm{ZrO}_{2}-2 \mathrm{Al}\right)$ were fabricated through mechanical alloying process followed by vacuum hot pressing. The results are summarized as follows:

- The nanocrystalline size of $3.5 \mathrm{~nm}$ and $2.6 \mathrm{~nm}$ were obtained at 20 hours of milling for sample 1 and sample 2 respectively.

- The highest hot pressed density of $7.32 \mathrm{~g} / \mathrm{cc}$ (96\% theoretical density) was obtained for aluminum- free ferritic 
ODS steel (sample 1) pressure of $60 \mathrm{MPa}$.

- Microstructures of sample 1 and sample 2 containing ferrite along with complex oxides such as (Y-Zr-O) and (Y$\mathrm{Al}-\mathrm{Zr}-\mathrm{O})$, which is evident from SEM-EDS analysis.

- Sample 1 has higher strength and hardness compared with sample 2, however \%

- Elongation was reduced.

\section{ACKNOWLEDGMENTS}

The authors would like to thank the Hon'ble Chairman, Veltech University, Chennai, India for providing the research facilities and also to publish the research paper. The authors would like to express their gratitude to M/s SANDVIK for supplying the $430 \mathrm{~L}$ ferritic stainless steel.

\section{REFERENCES}

1. R. Klueh, K. Ehrlich, F. Abe, Journal of nuclear materials, 191 (1992) 116-124.

2. H. Y. Kim, O. Y. Kwon, J. Jang, S. H. Hong, Scripta materialia, 54 (2006) 1703-1707.

3. J. Henry, X. Averty, Y. Dai, J. Pizzanelli, J. Espinas, Journal of Nuclear Materials, 386 (2009) 345-348.

4. A. Alamo, V. Lambard, X. Averty, M. Mathon, Journal of Nuclear Materials, 329 (2004) 333-337.

5. S. Noh, R. Kasada, A. Kimura, S. H. C. Park, S. Hirano, Journal of Nuclear Materials, 417 (2011) 245-248.

6. D. A. McClintock, M. A. Sokolov, D. T. Hoelzer, R. K. Nanstad, Journal of Nuclear Materials, 392 (2009) 353-359.

7. L. Guo, C. Jia, B. Hu, H. Li, Materials Science and Engineering: A, 527 (2010) 5220-5224.

8. K. Asano, Y. Kohno, A. Kohyama, T. Suzuki, H. Kusanagi, Journal of Nuclear Materials, 155 (1988) 928-934.

9. M. Li, Z. Zhou, P. He, L. Liao, Y. Xu, C. Ge, Fusion Engineering and Design, 85 (2010) 1573-1576.

10. P. He, M. Klimenkov, R. Lindau, A. Möslang, Journal of Nuclear Materials, 428 (2012) 131-138.

11. M. Miller, D. Hoelzer, E. Kenik, K. Russell, Intermetallics, 13 (2005) 387-392.

12. T. Liu, C. Wang, H. Shen, W. Chou, N. Y. Iwata, A. Kimura, Corrosion Science, 76 (2013) 310-316.

13. G. Pintsuk, Z. Oksiuta, J. Linke, N. Baluc, Journal of Nuclear Materials, 396 (2010) 20-25.

14. A. Karch, D. Sornin, F. Barcelo, S. Bosonnet, Y. De Carlan, R. Logé, Journal of Nuclear Materials, 459 (2015) 53-61.

15. P. Susila, D. Sturm, M. Heilmaier, B. Murty, V. S. Sarma, Materials Science and Engineering: A, 528 (2011) 4579-4584.

16. Z. Oksiuta, A. Ozieblo, K. Perkowski, M. Osuchowski, M. Lewandowska, Fusion Engineering and Design, 89 (2014) 137-141.

17. H. Sandim, R. Renzetti, A. Padilha, D. Raabe, M. Klimenkov, R. Lindau, A. Möslang, Materials Science and Engineering: A, 527 (2010) 3602-3608.

18. J. Macías-Delgado, T. Leguey, V. De Castro, M. Auger, M. Monge, P. Spätig, N. Baluc, R. Pareja, Nuclear Materials and Energy, 9 (2016) 372-377.

19. H. Sakasegawa, L. Chaffron, F. Legendre, M. Brocq, L. Boulanger, S. Poissonnet, Y. De Carlan, J. Bechade, T. Cozzika, J. Malaplate, Journal of Nuclear Materials, 386 (2009) 511-514.

20. Z. Oksiuta, E. Och, acta mechanica et automatica, 7 (2013) 38-41. 
21. L. L. Hsiung, Lawrence Livermore National Laboratory (LLNL), Livermore, CA, 2010.

22. G. Sundararajan, R. Vijay, A. Reddy, Current Science, (2013) 1100-1106.

23. Y. Xia, X. Wang, Z. Zhuang, Q. Sun, T. Zhang, Q. Fang, T. Hao, C. Liu, Journal of Nuclear Materials, 432 (2013) $198-204$.

24. R. Gao, T. Zhang, X. Wang, Q. Fang, C. Liu, Journal of Nuclear Materials, 444 (2014) 462-468.

25. A. Yabuuchi, M. Maekawa, A. Kawasuso, Journal of Nuclear Materials, 430 (2012) 190-193.

26. A. García-Junceda, N. García-Rodríguez, M. Campos, M. Cartón-Cordero, J. M. Torralba, Journal of the American Ceramic Society, 98 (2015) 3582-3587.

27. S. K. Karak, J. D. Majumdar, Z. Witczak, W. Lojkowski, Ł. Ciupiński, K. Kurzydłowski, I. Manna, Metallurgical and Materials Transactions A, 44 (2013) 2884-2894.

28. A. Kimura, R. Kasada, N. Iwata, H. Kishimoto, C. Zhang, J. Isselin, P. Dou, J. Lee, N. Muthukumar, T. Okuda, Journal of Nuclear Materials, 417 (2011) 176-179.

29. C. Suryanarayana, Progress in materials science, 46 (2001) 1-184.

30. C. Suryanarayana, E. Ivanov, V. Boldyrev, Materials Science and Engineering: A, 304 (2001) 151-158.

31. S. Karak, T. Chudoba, Z. Witczak, W. Lojkowski, I. Manna, Materials Science and Engineering: A, 528 (2011) 7475-7483.

32. S. Karak, J. D. Majumdar, Z. Witczak, W. Lojkowski, I. Manna, Materials Science and Engineering: A, 580 (2013) $231-241$.

33. Q. Zhao, L. Yu, Y. Liu, H. Li, Advanced Powder Technology, 26 (2015) 1578-1582.

34. J. H. Schneibel, C. T. Liu, D. T. Hoelzer, M. J. Mills, P. Sarosi, T. Hayashi, U. Wendt, H. Heyse, Scripta Materialia, 57 (2007) 1040-1043.

35. A. García-Junceda, M. Campos, N. García-Rodríguez, J. M. Torralba, Metallurgical and Materials Transactions A, 47 (2016) 5325-5333.

36. Z. Oksiuta, N. L. Baluc, Advanced Materials Research, Trans Tech Publ, 2009, pp. 308-312.

37. T. Liu, L. Wang, C. Wang, H. Shen, H. Zhang, Materials \& Design, 88 (2015) 862-870.

38. M. Taguchi, H. Sumitomo, R. Ishibashi, Y. Aono, Materials transactions, 49 (2008) 1303-1310.

39. M. Alinger, G. Odette, D. Hoelzer, Acta Materialia, 57 (2009) 392-406.

40. K. N. Allahar, J. Burns, B. Jaques, Y. Wu, I. Charit, J. Cole, D. P. Butt, Journal of Nuclear Materials, 443 (2013) $256-265$. 